\title{
Late Proterozoic Patsy Springs Canyon, Adelaide Geosyncline: submarine or subaerial origin?
}

\author{
C. C. VON DER BORCH, A. E. GRADY, K. H. EICKHOFF, P. DIBONA and N. CHRISTIE- \\ BLICK* \\ School of Earth Sciences, The Flinders University of South Australia, Bedford Park, South Australia, 5042, Australia \\ and * Department of Geological Sciences, Lamont-Doherty Geological Observatory of Columbia University, \\ Palisades, New York 10964, USA
}

\begin{abstract}
A significant aspect of Late Proterozoic sedimentation in the Adelaide Geosyncline, South Australia, is the presence of kilometre-deep erosional incisions which have been termed canyons. These structures were formerly described to be of submarine origin, cut and filled in an inferred basin-slope setting by subaqueous processes. Subsequent detailed research, particularly on a specific incision known as Patsy Springs Canyon, indicates that sedimentary structures within some of the canyon-filling sediments are indicative of deposition above fair weather wave base. In addition, an unusual carbonate unit, which is observed to veneer upper portions of canyon shoulders and to contribute to carbonate breccias interbedded with canyon-fill, has a stable isotope signature which may imply a non-marine origin. The presence of the carbonate veneer, where it is in situ, suggests that at least upper portions of the canyons could have been emergent during the canyon-filling phase. Considering these observations, and combining them with regional stratigraphical relationships, an alternative model for canyon genesis is proposed involving subaerial erosion and subsequent filling by coastal onlap. Such a model requires base-level changes of the order of $1 \mathrm{~km}$, in order to account for observed canyon cutting and filling. Vertical movements associated with halokinesis, or thermally-induced uplift of the order of $1 \mathrm{~km}$, could have resulted in the observed erosional events. Alternatively, a Messinian-style evaporitic lowering of base-level is currently receiving serious attention. With present knowledge this mechanism most satisfactorily explains all observations.
\end{abstract}

\section{INTRODUCTION}

Several kilometre-deep depressions filled with Late Proterozoic sediments occur within the Adelaide Geosyncline. These depressions appear to be erosional in nature, and have variously been referred to as canyons or erosional incisions. They outcrop throughout the central and northern Adelaide Geosyncline (Flinders Ranges) of South Australia (Fig. 1). The best exposed and structurally least disrupted examples occur in the northern regions. The canyons appear to have been eroded from a stratigraphical level (Fig. 2) within the Wonoka Formation (von der Borch, Christie-Blick \& Grady, 1988), into what clearly were already indurated Late Proterozoic strata comprising three major depositional sequences. Von der Borch, Smit \& Grady (1982) and von der Borch, et al., (1985) formerly described these incisions as submarine canyons and attributed their origin to processes of submarine erosion followed by marine-onlap filling. Since then Eickhoff, von der Borch \& Grady (1986), and subsequently members of I.A.S. Excursion $27 \mathrm{~b}$ (1986) have identified specific sedimentary structures which cast doubt on the simple submarine erosion model but which could support an origin by subaerial erosion and subsequently infilling by coastal onlap. Stable isotope studies of specific carbonate units (Eickhoff et al., 1988), although incomplete, also tend to favour subaerial derivation.

Each of the models has significant but contrasting implications with respect to major processes which were active during Late Proterozoic sedimentation 


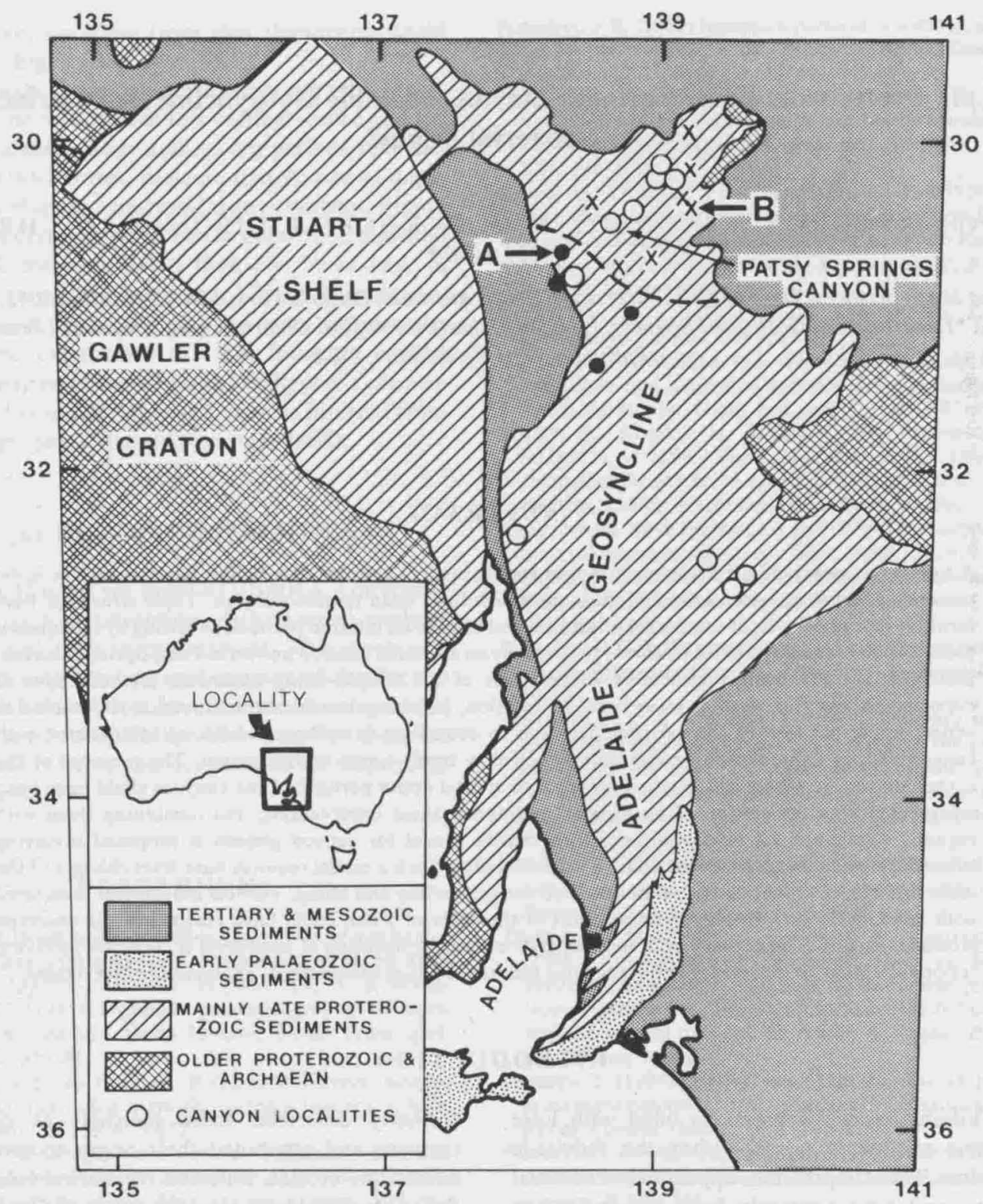

Fig. 1. Distribution of outcropping Late Proterozoic strata in South Australia; (A) and (B) denote the two typical stratigraphic sections of Fig. 13. Locations of prominent Late Proterozoic canyons are shown as open circles; dots indicate stratigraphic sections where Wonoka Formation unit 2 sandstones (see Fig. 13) are present; crosses indicate sections where unit 2 sandstones are absent or poorly developed, in some cases associated with peritidal indicators in underlying unit 1; the dashed line separates the regions typified by each section.

within the region. Correct interpretation also bears upon studies of sequence stratigraphy and the causes of sequence boundary formation in the Late Proterozoic, a subject which currently is receiving considerable attention (DiBona \& von der Borch, 1986; von der
Borch et al., 1988; Christie-Blick, Grotzinger \& von der Borch, 1988). This paper critically evaluates the evidence provided by lithologies and sedimentary structures in a measured stratigraphical section through canyon-filling sediments of Patsy Springs 


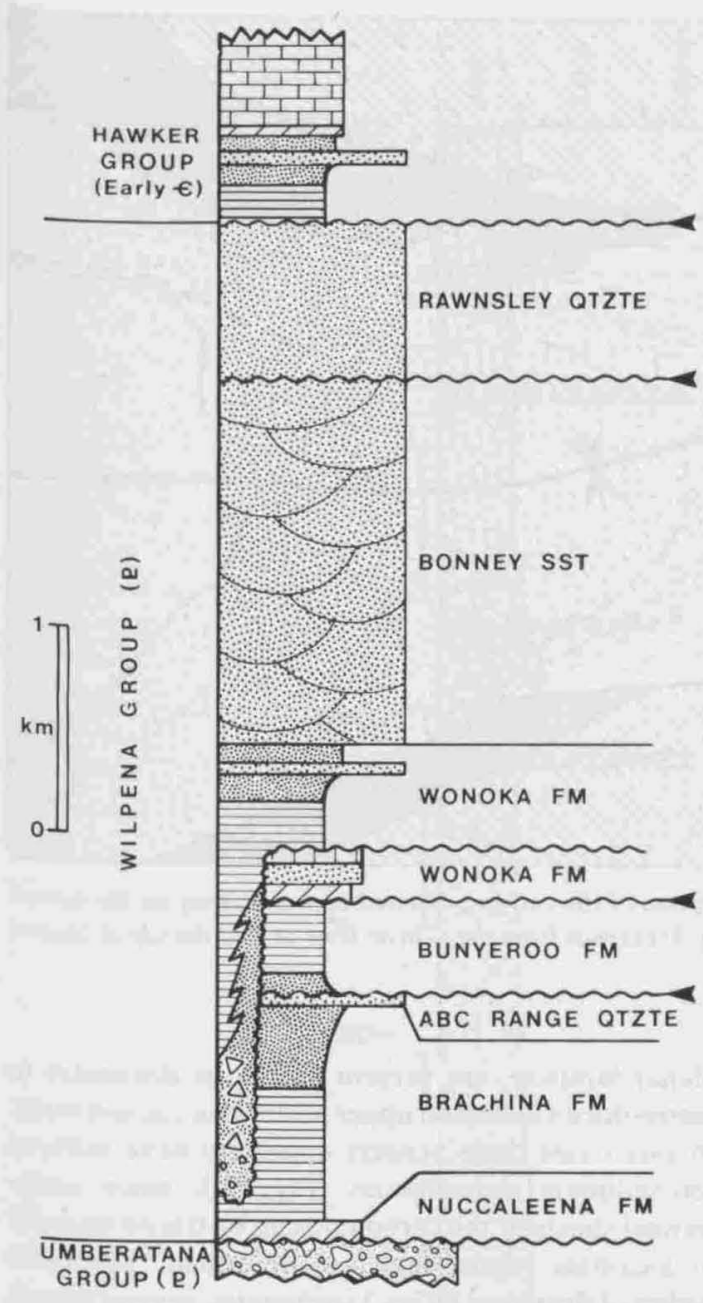

Fig. 2. Generalized stratigraphy of Late Proterozoic Wilpena Group, Adelaide Geosyncline. Arrows indicate prominent sequence boundaries. Note the canyon incision into Brachina Formation from a stratigraphic level within Wonoka Formation.

Canyon (Figs 1 \& 3) and surrounding strata. Brief references are also made to related canyons which outcrop to the north of Patsy Springs Canyon (Fig. 1). The significance of the unusual carbonate veneers which were deposited on canyon shoulders and slopes during and following the erosional event also is discussed, and models are considered for canyon erosion and filling. Implications of what now is the favoured model, relating to subaerial canyon erosion, will be evaluated in the context of sequence stratigraphy and relevant syndepositional events.
Stratigraphic nomenclature relating to the Bunyeroo-Wonoka Formation boundary, adopted in this paper, is that of Gostin \& Jenkins (1983) and Haines (1986a, 1988). The overall setting of the Adelaide Geosyncline is summarized in von der Borch (1980), Rutland et al. (1981) and Preiss (1987).

\section{LITHOFACIES OF CANYON FILL}

Figure 3 illustrates the relationship of Pasty Springs Canyon to underlying Late Proterozoic sequences and to a regional Cambro-Ordovician compressional orogenic event (Preiss, 1987) which folded Adelaide Geosyncline strata and presumably produced structures such as the Angepena Syncline. Attention is drawn to an earlier description of the facies of precanyon, canyon-fill and post-canyon sediments of Patsy Springs Canyon (von der Borch et al., 1982). Stratigraphic section $\mathrm{X}-\mathrm{Y}$ (Figs 3 \& 4) represents the detailed measured section of this study. Figure 4 illustrates the vertical extent of nine of the eleven facies units chosen for descriptive purposes.

\section{Details of facies units}

\section{Facies 1: basal canyon conglomerate}

Granule to boulder conglomerates (Fig. 5a) are present at the base of Patsy Springs Canyon. These conglomerate units, which range up to $2-3 \mathrm{~m}$ in thickness, are clast-supported and contain moderately to wellrounded clasts of micritic carbonate and quartzite, angular carbonate clasts, rare oolitic limestone clasts and greenish-grey to greyish-red chert pebbles. The largest clasts, usually quartzite, have diameters up to $50 \mathrm{~cm}$. Conglomerates are variously matrix free, with sparry calcite cement, or contain a matrix of medium to fine quartz sand grains and peloids. Locally chert, in the form of 'megaquartz', comprises late-stage void fill. Basement-derived clasts such as granites, gneisses and volcanic rocks are conspicuous by their absence, with the exception of very rare pebbles of acid volcanics possibly sourced by the 'Gawler Range Volcanics' on the Gawler Craton (Fig. 1). Conglomerates of facies 1 include both ordered and disordered varieties.

\section{Facies 2: massive and laminated sandstones}

The basal canyon-fill, both interbedded with as well as overlying facies 1 , is composed of massive to 


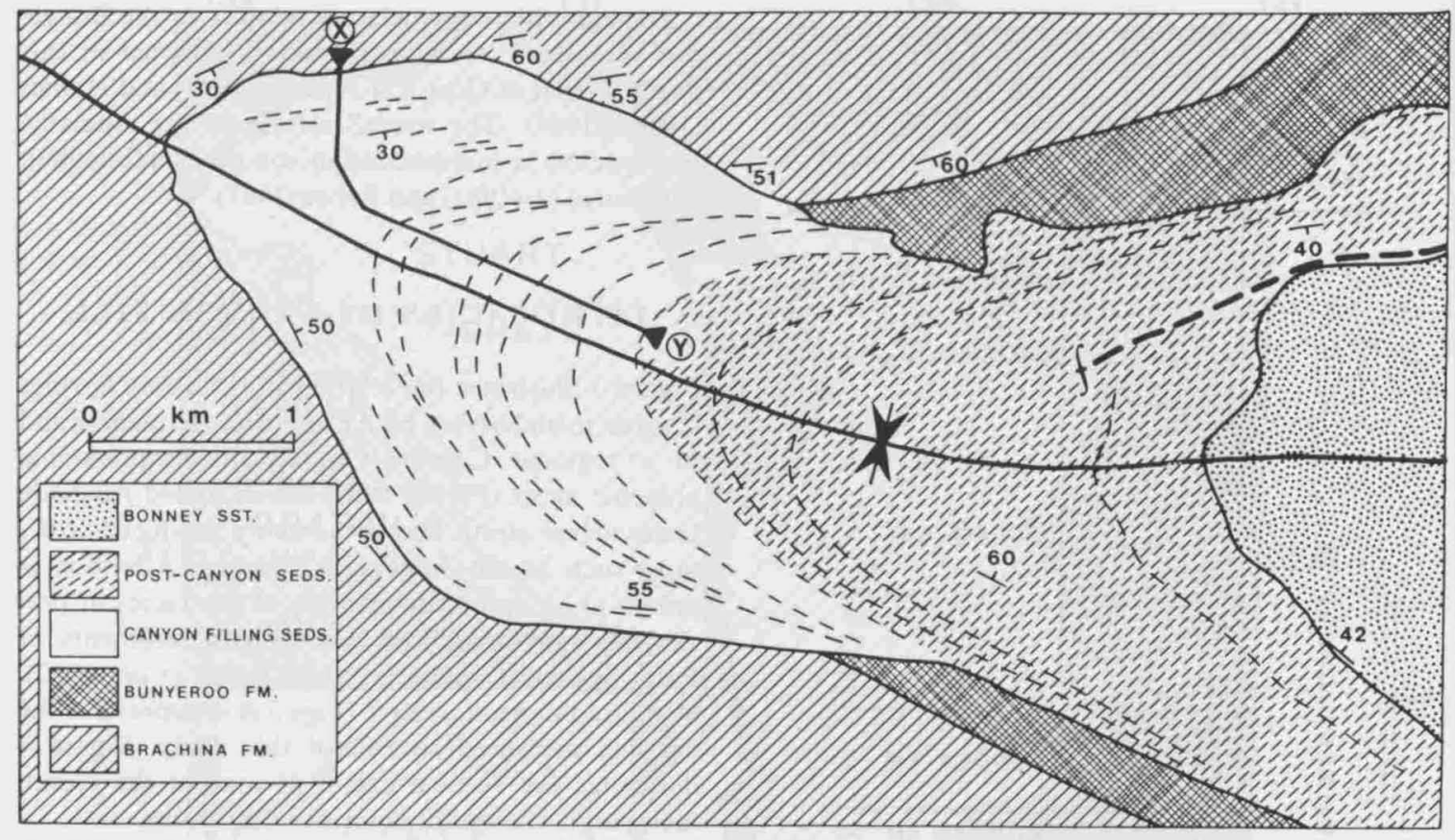

Fig. 3. Patsy Springs Canyon. See Fig. 1 for location. Note the location of the canyon, situated approximately on the axis of the Angepena Syncline. The location of measured section X-Y (Fig. 4) extends from the canyon floor at X to the top of canyon fill at $\mathrm{Y}$; structure form-lines are dashed.

diffusely parallel-laminated medium dark grey sandstones, locally with scattered rounded quartzite pebbles (Fig. 5b). Facies 2 sandstones occur in cyclic units 0.3-2 $\mathrm{m}$ thick. Sandstones commonly exhibit a spheroidal weathering pattern. Sandstone units may be stacked, or separated by minor $(0.02-0.03 \mathrm{~m})$ calcar- $^{-}$ eous mudstone interbeds. The sandstones commonly have sharp, and in many cases, load-cast bases, and their tops may be capped by mud-draped symmetrical ripples (Fig, 5c), symmetrical interference ripples, or less commonly by combined-flow ripples or by trough cross-beds in $0 \cdot 2-0.3 \mathrm{~m}$ sets. Rare, isolated occurrences of metre-thick sandstones show partial Bouma sequences of sedimentary structures. Millimetre-thick mud drapes and flasers are locally associated with ripple cross-laminae. Petrographically, facies 2 sandstones are well sorted. They are composed of fine to very fine angular quartz grains, rare feldspars and micas, and are cemented by sparry calcite.

\section{Facies 3: canyon shoulder carbonate veneers}

Yellowish-grey to pale-red micritic and microsparry limestones and dolomites, commonly with diffuse planar laminae, are present locally as decimetre to metre-thick veneers on upper portions of canyon walls. In rare cases these veneers appear to have suffered soft-sediment deformation (Fig. 6a), since undeformed sheets of the carbonate can be traced laterally to localities where they are deformed. Sheet-like bodies of displaced facies 3 carbonates, several metres in length and decimetres in thickness, locally overlie 1-2 m thick lenticular units of slumped canyon-wall mudstones of facies 6 . These distinctive facies 3 carbonates, when they are in situ, cannot be traced away from the eroded canyon edges, but lens out abruptly along the limbs of the Angepena syncline. The carbonates specifically veneer the eroded surface of either the Brachina or the Bunyeroo Formation. Clasts, as well as displaced and disrupted sheets (facies 4 , see below) derived from facies 3 , can be identified at most levels within canyon-filling sediments, usually as well-defined breccia bodies. Facies 3 carbonates locally show centimetre-sized features which resemble small stromatolites. Associated with the canyon near A (Fig. 1), facies 3 carbonates have developed cusp-like syndepositional structures which resemble large tepees, with amplitudes of several 


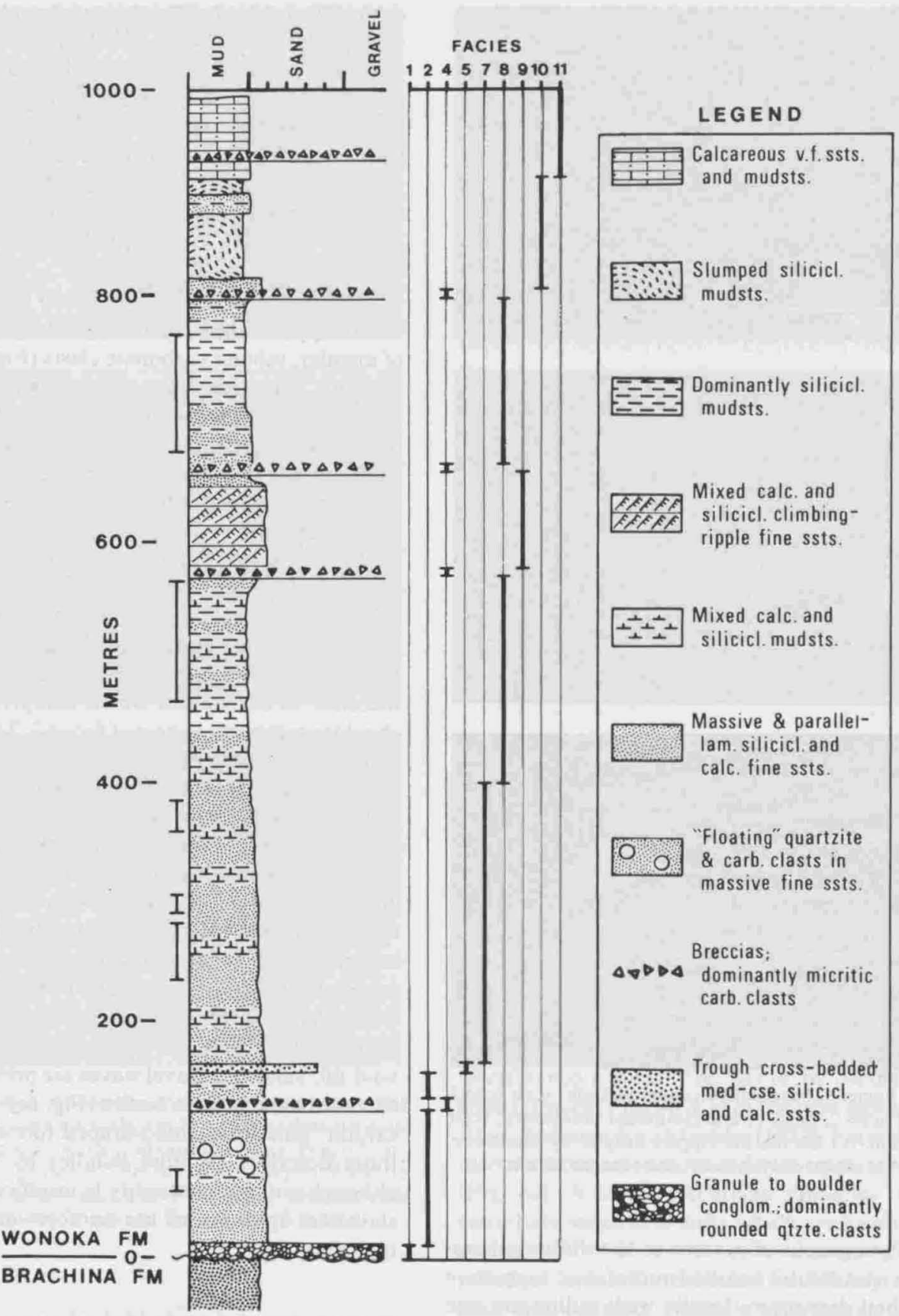

Fig. 4. Details of canyon-fill in measured section X-Y (Fig. 3). The vertical extent of each facies is indicated at the right (note that facies 3 and 6 are not intersected by section). The bars to the left of the column designate poor outcrop. 

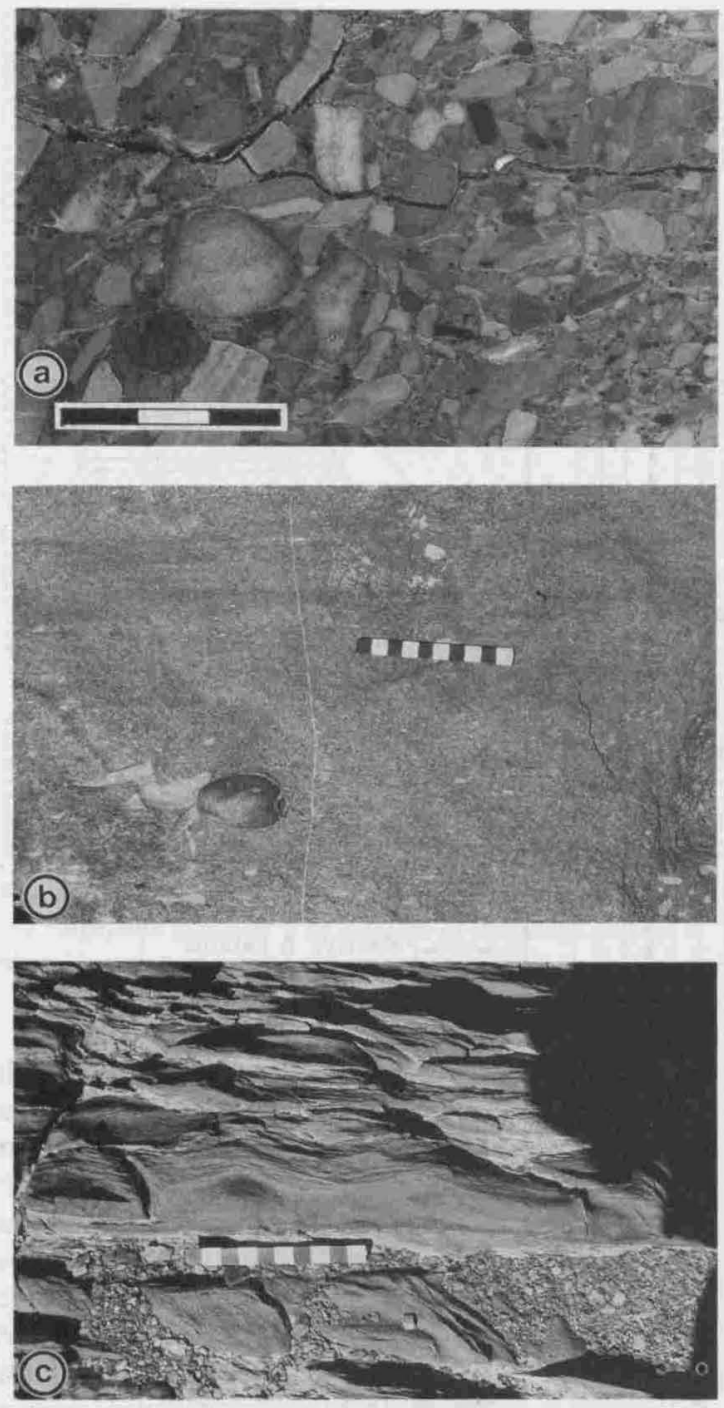

Fig. 5. (a) Facies 1, basal canyon conglomerate; scale length $3 \mathrm{~cm}$. (b) Facies 2, massive and laminated sandstones; scale length $10 \mathrm{~cm}$. (c) Oscillation ripples draped by mudstone, facies $2,24 \mathrm{~m}$ above canyon floor; scale length $10 \mathrm{~cm}$.

metres. Petrographically, some of the diffusely laminated micrites exhibit a clotted microfabric suggestive of microbial derivation, locally with millimetre size spar-filled voids interpreted as laminoid fenestrae. More commonly the carbonates have a relatively uniform micritic or microsparry fabric and contain scattered irregular grains of silt sized quartz of possible diagenetic origin. Preliminary whole-rock stable isotope studies have been carried out on a comparable carbonate veneer and associated breccias in canyons north of Patsy Springs (Eickhoff et al., in press). Negative value of $\delta^{13} \mathrm{C}$ (average $8.86 \%$ Pedee Formation Belemnite Standard) and $\delta^{18} \mathrm{O}$ (average $15.43 \%$ PDB) were obtained for both veneers and the dominant clasts in facies 4-type breccias in that area, although it is not known what effects, if any, that neomorphism has had on isotopic values.

\section{Facies 4 : carbonate-clast breccias}

Clast-supported breccias composed almost exclusively of angular, tabular carbonate clasts (Fig. 6b) occur as laterally extensive units throughout canyon-filling sediments. Rare clasts are observed to be slightly deformed, suggesting that at least some were derived from initially uncemented carbonates. Breccia bodies vary from centimetres to about $5 \mathrm{~m}$ in thickness. They are usually lenticular, and in some cases can be traced as discrete bodies for several hundred metres. Rare siltstone clasts, obviously derived from subcropping canyon walls, also occur in the breccias. The carbonate clasts, which are normally micritic to microsparry calcite but which are in some cases dolomicrite, are identical to carbonates which comprise the canyon shoulder carbonate veneer of facies 3 . The implication is that they were sourced by facies 3 which was concurrently developing high on the canyon walls. Tabular clasts in facies 4 breccias range up to several metres in length with an average size of about $0.01 \times$ $0.05 \mathrm{~m}$. Occasional clasts contain well-defined domal and locally digitate stromatolites with relief up to $0.3 \mathrm{~m}$. Breccias usually have a matrix of carbonate micrite, quartz sand, or rounded quartz granules. Less commonly, breccias are wholly or partly matrix-free, with calcite cement rinds around clasts, locally cherty sparry calcite void-fill, or geopetal carbonate mud void-fill. Sand and gravel waves are present at the tops of some of the breccia bodies (Fig. 6c). Locally, these exhibit 'bundles' of mud-draped foresets resembling those described as tidal bundles by Visser (1980), although outcrop continuity is insufficient to make a statistical appraisal of the numbers of couplets in a typical cycle.

\section{Facies 5 : trough cross-bedded calcareous sandstone}

These sandstones (Fig. 7a) are present as a restricted facies, consisting of one to two beds up to $2.5 \mathrm{~m}$ thick, located about $150 \mathrm{~m}$ above the base of Pasty Springs Canyon. Trough cross-bedding, with $0 \cdot 2-0.3 \mathrm{~m}$ set heights and parallel laminae, dominate the sedimen- 

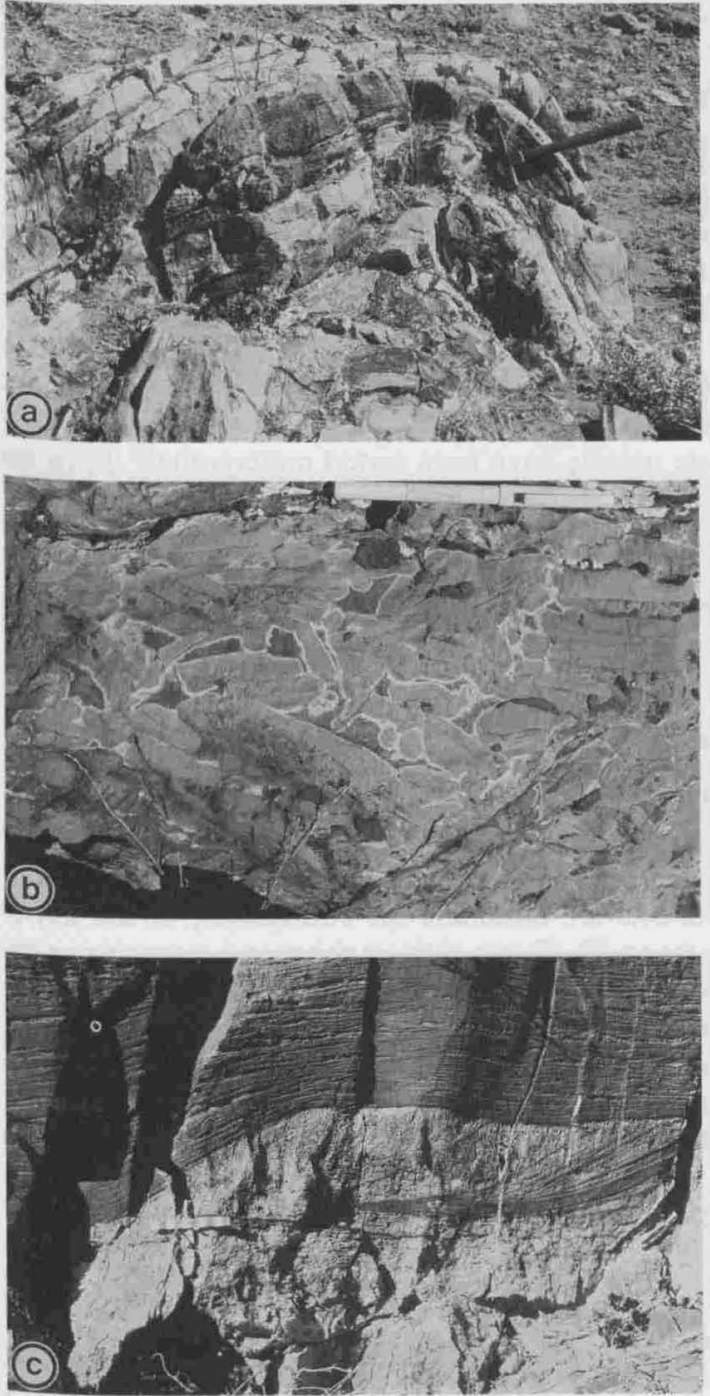

Fig. 6. (a) Facies 3, canyon shoulder carbonate veneer; note slump fold; hammer for scale. (b) Facies 4, carbonate-clast breccia; note sparry calcite rinds around clasts. Pen, $0.15 \mathrm{~m}$, for scale. (c) Sandwave, $800 \mathrm{~m}$ above canyon floor, in calcirudite-calcarenite unit above carbonate breccia; note possible tidal bundles. For scale, the pen is $0.15 \mathrm{~m}$ long.

tary structures. The typically greyish-red sandstones have a variable lithology, comprising medium to coarse, angular to well-rounded quartz grains, carbonate peloids, and what appear as medium to coarse sand-sized crystalline calcite grains. Sparry calcite cement is common, associated with abundant hae- matite and chlorite. Occasional greyish-red mudstone intraclasts have been incorporated into the sandstones, which have locally channelled up to $0.2 \mathrm{~m}$ into underlying very fine sandstones and mudstones.

\section{Facies 6: wall slumps}

Clast and matrix-supported terrigenous diamictites (Fig. 7b) commonly mantle canyon walls as lenticular units up to several metres in thickness. The diamictites vary in colour from greyish-red to dark greenish-grey, depending on their obvious derivation either from the Bunyeroo or Brachina Formation subcrop on canyon walls. The diamictites have also locally been emplaced into the canyon and are interbedded with other canyon-filling sediments. Rare tabular carbonate clasts, similar to facies 3 carbonates, have been incorporated into some of the diamictites, and sheetlike bodies of facies 3 carbonates locally appear to have been displaced into the canyon-fill with some of the diamictites. Isolated clasts derived both from Brachina and Bunyeroo Formation subcrops on canyon walls, occur in the wall-mantling diamictites almost to the base of the canyon-fill.

\section{Facies 7: calcareous sandstones and mudstones}

This facies type forms a significant unit of the lower canyon-filling sediments in Patsy Springs Canyon. Sandstones are very fine to fine quartz, rare feldspar and carbonate peloid sands, greenish-grey in colour, interbedded with thin $(c .0 \cdot 01-0.02 \mathrm{~m})$, dark greenishgrey calcareous mudstones. Sparry calcite cement is common. Most sandstone beds of facies 7 have sharp bases. Typically, individual parallel-laminated to current-rippled sands are capped by symmetrical interference ripples (Fig. 8a) or by oscillation-influenced ripples (Figs $8 \mathrm{~b} \& \mathrm{c}$ ) of the type described by de Raaf, Boersma \& van Gelder (1977). Form-discordant internal structures associated with ripples are common (Fig. 8c). A locally occurring subfacies of facies 7 comprises sandstone units which are locally cyclic in nature, with $0.08-0.1 \mathrm{~m}$ thick cycles (Fig. 9a) composed of upwardly thinning and fining calcareous mud-sand couplets, typically with the relatively thick basal sand beds exhibiting loaded ripples and load casts into thin underlying mudstones. Counts of sandmud couplets in four individual cycles indicate 28 per cycle (Fig. 9b). Limited outcrop of facies 7 makes it impossible to determine the large-scale geometry of this unit. Hummocky cross-stratification (HCS) is a 

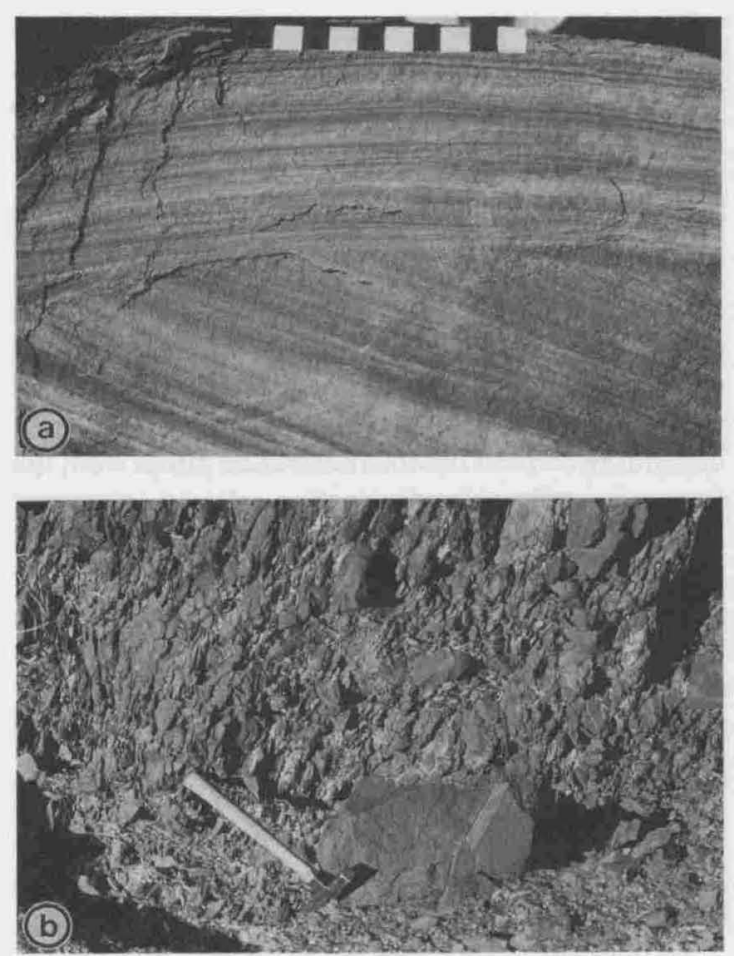

Fig. 7. (a) Facies 5, cross-bedded calcareous sandstone; scale length $0.1 \mathrm{~m}$. (b) Facies 6 , wall slumps; hammer for scale.

significant structure in some fine-grained sandstone units of facies 7 .

\section{Facies 8: mudstones}

Light olive-grey to greenish-grey calcareous mudstones (Fig. 10a) are present in regions of poor exposure within mid to upper portions of the canyonfilling sediments. Mudstones are commonly streaked with millimetre bands and lenticles of very fine quartz and carbonate sand and coarse silt. Local climbingripple sets form slightly more prominent beds within the background mudstones. Small-scale (several mm) load and flame structures are abundant.

\section{Facies 9: climbing-ripple sandstones}

A lenticular sandstone unit, approximately $60 \mathrm{~m}$ in thickness, forms a prominent outcrop spanning the width of Patsy Springs Canyon. The sandstone thins out against northern and southern canyon walls. Spectacular sets of climbing ripples (Fig. 10b), associated with planar-laminated sandstones, are typical of facies 9. Centimetre-thick interbeds of mudstone are usually loaded by basal portions of overlying climbing-ripple sandstones. Climbing-ripple sandstones tend to be amalgamated. They comprise metre-scale cycles, each of which may contain several climbing-ripple sets. Cycles generally have abrupt tops and a typical cycle is overlain by decimetre-scale recessive units of mudstones and very fine sandstones. Sandstones are composed of fine to very fine quartz and feldspar grains and abundant micritic peloids, cemented by sparry calcite. Carbonate peloids have been sorted preferentially down lee sides of ripples where they have weathered recessively (Fig. 10b). Quartz sand- and mud-rich laminae are closely spaced on stoss sides of climbing ripples which consequently weather in relief. Local combined-flow ripples are observed in association with facies 9 .

\section{Facies 10: megaslump}

Thick units of chaotically slumped greenish-grey siliciclastic mudstone (Fig. 11a), separated by several metres of interbedded mudstones and very fine sandstones, dominate the stratigraphy of the upper canyon fill. Slump rolls up to several metres in crosssection characterize this facies, which also contains local clasts obviously derived from canyon wall sediments. Tabular clasts of facies 3 carbonates are incorporated into some of the slumped mudstones. Truncated current ripples and combined-flow ripples (Fig. $11 \mathrm{~b} \& \mathrm{c}$ ) are associated with sandstones and mudstones which are interbedded with the slumped units.

\section{Facies 11: rhythmites}

The uppermost canyon fill is composed of interbedded peloidal and siliciclastic very fine sandstones with sparry calcite cement, and mudstones, in rhythmic $0.01-0.05 \mathrm{~m}$ intercalations. Metre-scale channelling and associated carbonate-clast breccia bodies are found (Fig. 12) with some breccias measuring metres in thickness and extending for several hundred metres across the canyon section. This unit appears to have 'topped-up' the final topographic depression of the canyon (Fig. 3). It grades upsection to monotonous olive-grey mudstones and local interbedded carbonate-clast breccias. The overlying strata at Patsy Springs Canyon comprises an upward-coarsening succession of upper Wonoka Formation siliciclastics and rare facies 4 carbonate clast breccias. 

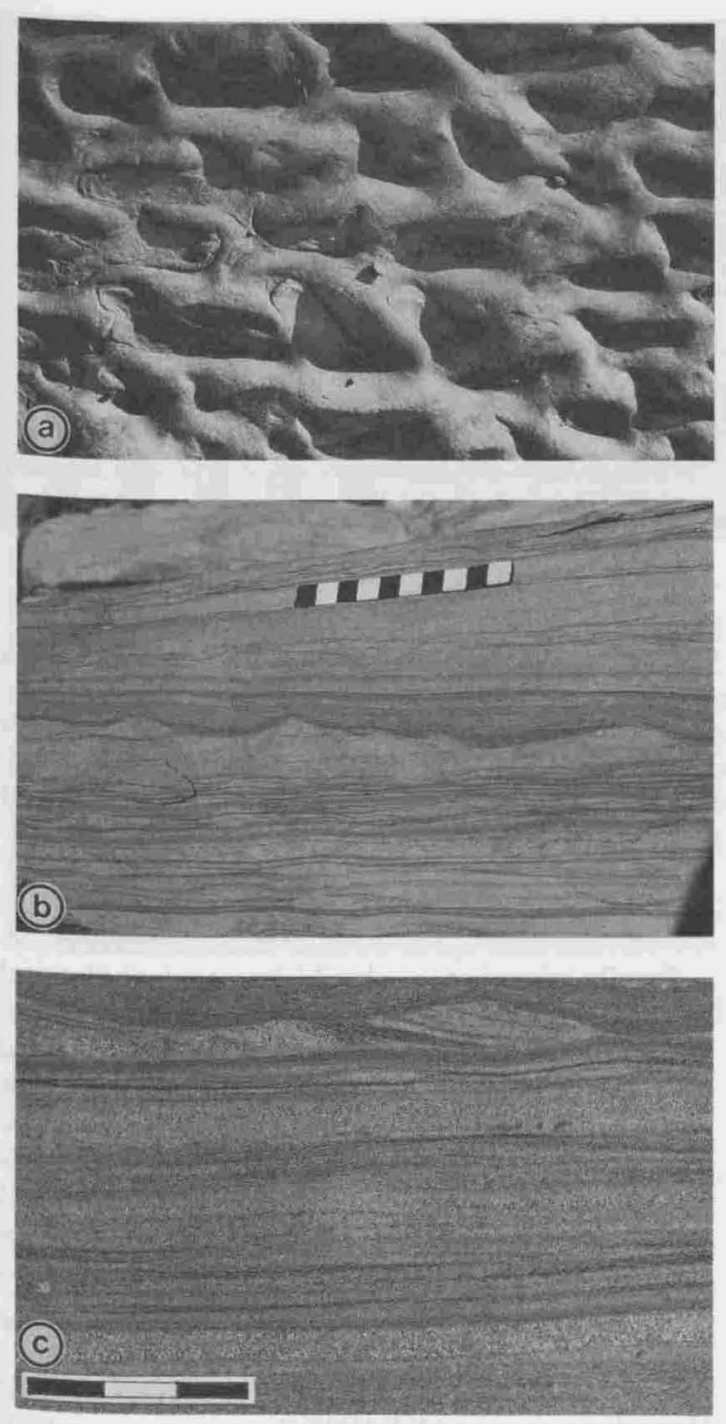

Fig. 8. (a) Interference oscillation ripples on sharp top of very fine calcareous sandstone, facies 7 , approximately $200 \mathrm{~m}$ above canyon floor. The width shown in the photograph is $0.5 \mathrm{~m}$. (b) Oscillation-influenced ripples draped by muds, facies $7,210 \mathrm{~m}$ above canyon floor; scale length $0.1 \mathrm{~m}$. (c) Form-discordant combined-flow ripples in facies $7,210 \mathrm{~m}$ above canyon floor; scale length $0.03 \mathrm{~m}$.

\section{SUMMARY AND DISCUSSION}

\section{Sedimentary structures}

Specific sedimentary structures associated with various facies of canyon-filling sediments have already been described. The following section presents an interpretation of these structures and an evaluation of their significance with respect to palaeobathymetry.

Many sand beds within the canyon-filling sediments of Patsy Springs Canyon contain features indicative of specific and of ten energetic pulses of sedimentation. Many of the ripples associated with these sands, as described above, have undulatory bases and possess the form-discordant nature of combined-flow ripples (Fig. 8c). Such structures are indicative of deposition under the joint influence of wave-induced oscillatory processes and unidirectional current flow. This type of structure is, in fact, quite common throughout the canyon fill. Interference ripples, observed on the tops of many of these sandstones, usually have a symmetrical morphology (Fig. 8a), again implying an oscillatory influence. In other cases entire sandstone beds are made up of combined-flow ripples (Fig. 11c) which show such features as 'offshoots' (de Raaf et al., 1977). Such structures are typical of wave ripples. Considered overall, the preferred interpretation of this suite of sedimentary structures is that water depth, during much of the canyon-filling process, was less than that of fair weather wave base.

Examples of HCS have been observed in Patsy Springs Canyon sediments, for example associated with facies 7 sandstones in lower canyon fill. Well defined HCS has also been described in similar facies within comparable canyons which outcrop to the north of Patsy Springs (Eickhoff et al., 1988). Although structures resembling HCS have been documented in deep water sediments (Prave, 1985), it is normally regarded as indicating deposition above storm wave base. This suggests that a significant proportion of the fill of Patsy Springs Canyon, particularly facies 7, was deposited in such a situation.

Structures which resemble truncated ripples (Fig. 11 b) are occasionally observed near the base of Patsy Springs Canyon sediments. Better preserved examples have been documented in the closely related northern canyons. Their presence indicates some process which modified ripple morphologies following their formation. The most likely mechanism is related to the action of waves in very shallow to intermittently exposed environments.

Two somewhat contrasting sedimentary structure associations have been described which suggest some form of tidal influence upon sedimentation during canyon filling. These are the locally occurring repetitive cycles observed as a sub-facies of facies 7 , and what appear to be isolated tidal bundles in the rare sand waves of facies 4 .

A typical repetitive cycle (Fig. 9b) contains 28 


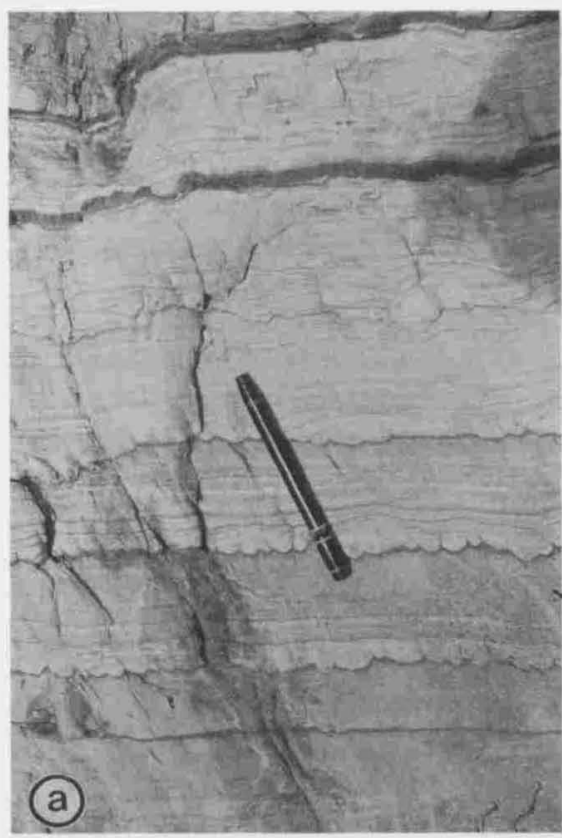

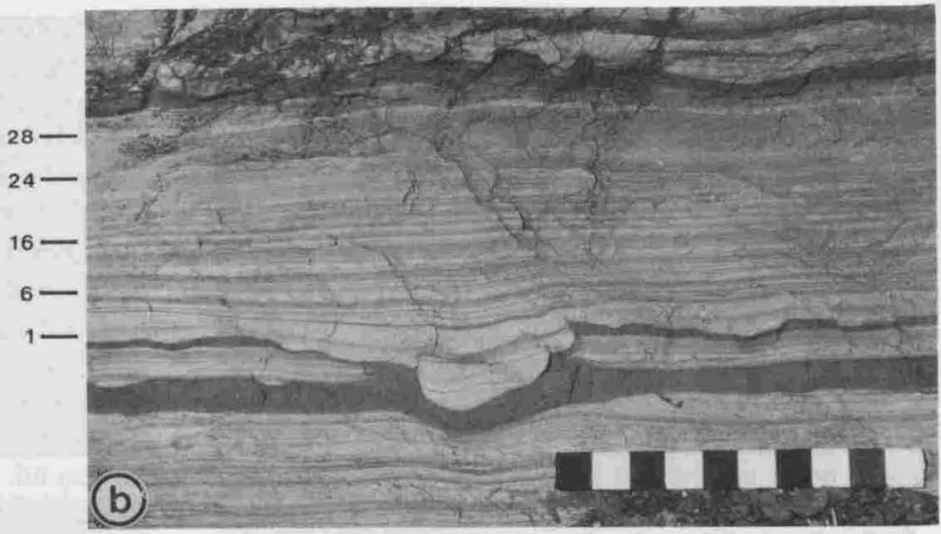

Fig, 9. (a) Facies 7, calcareous sandstones and mudstones. For scale, the pen is $0.15 \mathrm{~m}$ long. Note 8 cycles, with loaded ripples and load casts at base of each. (b) Details of facies 7, 200 m above canyon floor, illustrating a single cycle with load casts at base. Note upwards-thinning of light-coloured sandstone layers and increasing prominence of mudstone layers up-section. Note also the presence of c. 28 mud-sand couplets in cycle. Scale length $0.1 \mathrm{~m}$. upward-fining sand-mud couplets. Exposure is insufficient to allow delineation of overall geometry of this sub-facies. However, it is clear that the association cannot simply be related to the classical concept of tidal bundles in sand wave foresets, as outlined by Visser (1980). At this stage all that can be concluded is that the number of couplets implies some form of tidal control, while the actual mechanism remains undetermined.

The 'bundling' of sand-mud couplets, observed in rare sand waves associated with facies 4 carbonate breccias, resembles classical tidal bundles. In this case the sparse occurrence of such sand waves, and their lack of continuity, do not allow a reliable estimate to be made of average numbers of couplets in a single cycle. As with the previous example, tidal control is a plausible mechanism.

The above observations underscore the possibility that shallow water tidally-influenced conditions existed during deposition of the canyon fill. However, a degree of uncertainty is introduced by the incomplete nature of the sedimentary evidence. The fact that tidal currents have also been detected in modern submarine canyons (Shepard, Marshall \& McLoughlin, 1974) and that such currents could develop a comparable sedimentary signature, detracts from the critical value of these sedimentary structures.
Finally, the absence should be noted of classical turbidites within the fill of Patsy Springs Canyon. Flysch-like turbidites are common in many described examples of ancient submarine canyon-fills (see for example Carter, 1979). In fact, turbidites would be expected to constitute a significant facies in such environments. Their absence provides additional support for the shallow-water setting of deposition in Patsy Springs Canyon.

\section{CANYON SHOULDER CARBONATE VENEER}

The unusual facies 3 carbonates mantling upper walls and shoulders of the canyons, and related facies 4 breccias, may have a bearing on the mode of canyon formation. Stable isotope measurements on these, although preliminary and non-specific with regards to fabric, suggest a non-marine origin for the veneer and associated carbonate breccias. The highly negative carbon values are considered also to imply a microbial origin (Eickhoff et al, 1988). Well formed stromatolites occasionally found in clasts of facies 4 breccias within Patsy Springs Canyon, and the local occurrence of clotted microfabrics in facies 3 , support a shallow water or subaerial origin for facies 3 carbonates. 

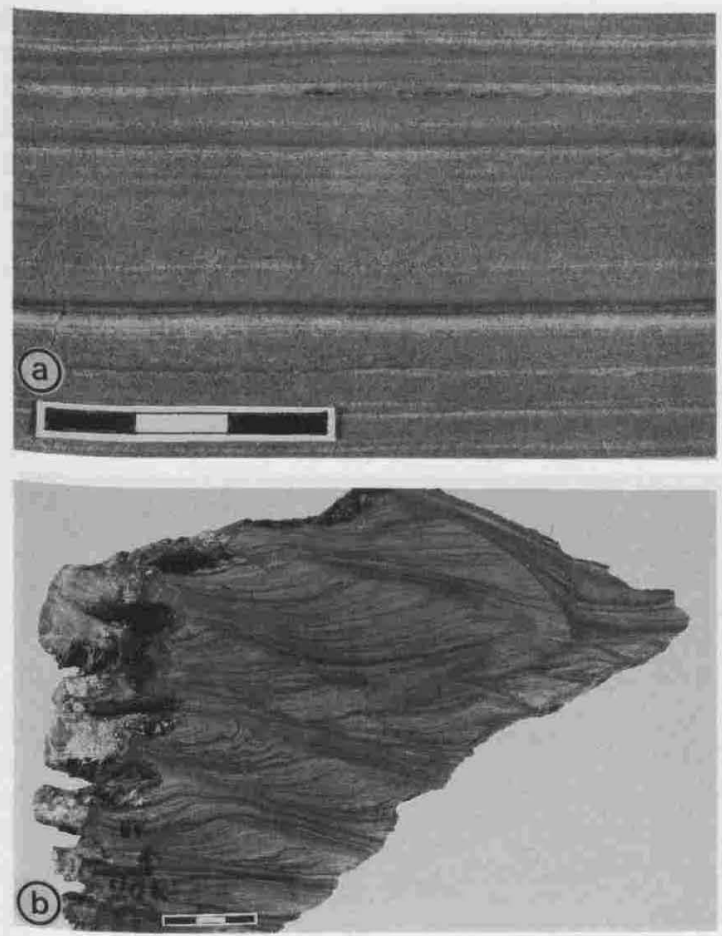

Fig. 10. (a) Facies 8, mudstones; scale length $30 \mathrm{~mm}$. (b) Facies 9, climbing ripple sandstones; scale length $30 \mathrm{~mm}$. Note recessive weathering on left side, reflecting high $\mathrm{CaCO}_{3}$ content on lee sides of ripples.

The carbonate veneer, on present evidence, is interpreted to have developed under the influence of groundwater discharge from subaerial canyon walls and from slopes adjacent to canyons. A distinct hydraulic gradient towards an eroded canyon would be the necessary result of slope change at a subaerial canyon rim. The normal process of loss of $\mathrm{CO}_{2}$ from discharging groundwaters would cause $\mathrm{CaCO}_{3}$ precipitation, with microbial mats and stromatolites locally leaving their imprints in the resulting carbonate. Such carbonates would probably resemble travertines and tufas. Consequently, they would be indurated during their formation. A possible modern analogue is a calcareous tufa associated with parts of the modern Grand Canyon (USA) wall (J. F. Mount, pers. comm., 1987). Mass movements related to lateral wasting of Patsy Springs Canyon walls could have caused downward displacement of veneer fragments as sheets and carbonate breccias. The observation that the breccias are interbedded with canyon-filling sediments implies several generations of veneer development and disruption during the canyon filling stage.

The presence of rare bent clasts in facies 4 breccias, and localized soft-sediment deformation of some veneer sheets, suggest that some of the carbonates of facies 3 were deposited as unconsolidated micrites. This could have occurred in localized shallow groundwater fed alkaline lakes, or by precipitation from shallow water during early stages of canyon inundation. A process of undercutting by mass-wasting, and subsequent downward displacement of disrupted carbonates, would account for the rare distorted breccia clasts and slump-folded carbonates. The large tepee-like structures may reflect localized peritidal carbonate crust expansion.

\section{REGIONAL STRATIGRAPHIC RELATIONSHIPS}

The Bunyeroo and Wonoka Formations span the interval during which the canyons were eroded and infilled. Regional variations in these formations are therefore considered critical for interpretation of depositional and structural settings of the canyons. Figure 13 illustrates measured stratigraphic sections through the Bunyeroo and Wonoka Formations which are typical of two contrasting regions in the northern Adelaide Geosyncline. Section A is representative of an area which is not normally associated with canyon erosion, while section B typifies an area of significant canyon development.

Above the ABC Range Quartzite in section A (Figs. 1 \& 13) lie approximately $500 \mathrm{~m}$ of monotonous, massive to finely-laminated greyish-red mudstones of the Bunyeroo Formation. This formation contains minor thin (several $\mathrm{cm}$ ) poorly-sorted lithic sandstone intercalations within its uppermost $0.5 \mathrm{~m}$. A widespread decimetre-thick dolomite breccia (unit 1 of Haines, 1986a, 1988) is present at the top of the Bunyeroo Formation. Above this lies a $100 \mathrm{~m}$ thick unit (unit 2 of Haines) comprising fine-grained, sharpbounded sandstones in centimetre to decimetre-thick beds, interbedded with minor greyish-red mudstones similar to those of the underlying Bunyeroo Formation. These sandstones are locally slightly graded, with occasional Bouma sequences. Small-scale HCS is commonly present and flute casts typically occur on the bases of beds. Unit 2 sandstones grade upsection to greyish-red mudstones which contain an increasing degree of intercalated thin $(0.01-0.05 \mathrm{~m})$ flaggy calcarenite and calcilutite beds (unit 3 of Haines). 

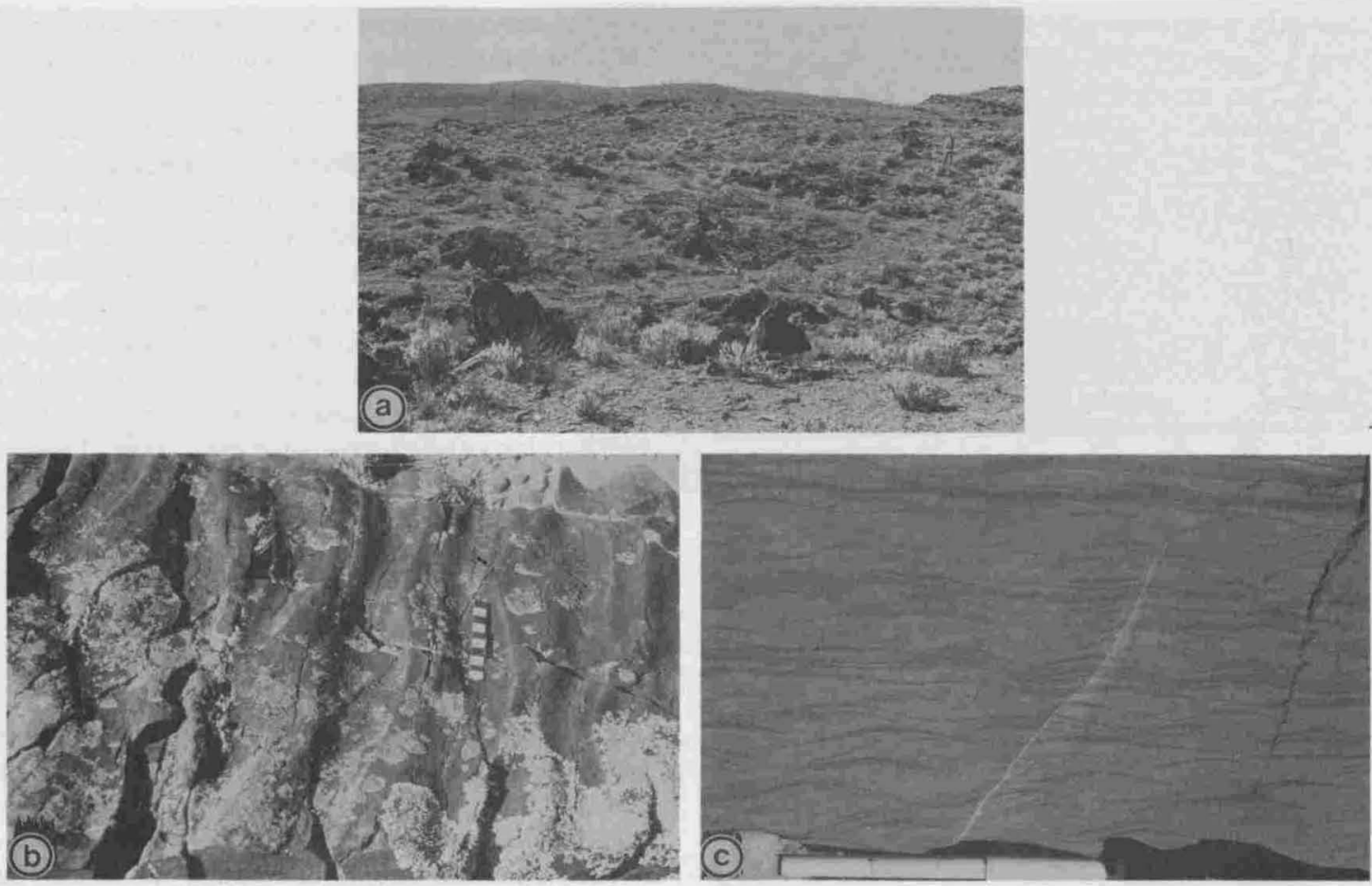

Fig. 11. (a) Facies 10, megaslump; figure on right for scale. Note chaotic arrangement of slump-folded clasts. (b) Truncated oscillation ripples at sharptop of fine sandstone, facies $10,810 \mathrm{~m}$ above canyon floor; scale length $0.1 \mathrm{~m}$. (c) Combined-flow ripples, facies 10,870 m above canyon floor; note dark-coloured mud-drapes and 'offshoots' in lighter-coloured sands. For scale the pen is $0.15 \mathrm{~m}$ long.

Further upsection, calcareous mudstones, interbedded fine calcareous sandstones and carbonate breccias are observed (unit 4 of Haines).

Section B (Fig. 13) exhibits a sharply defined lithological boundary at the base of the Bunyeroo

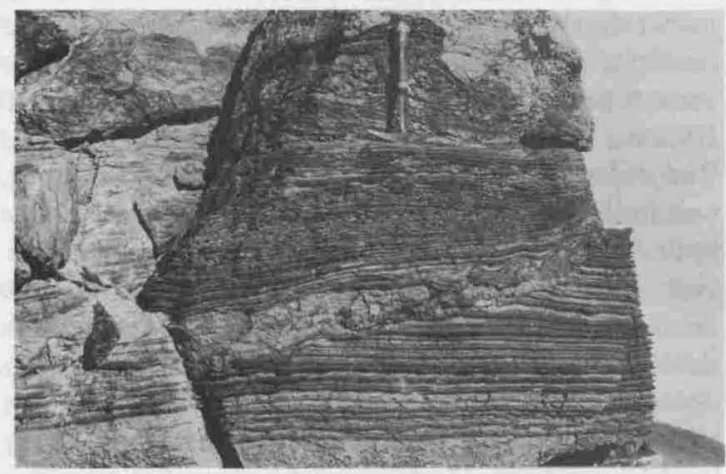

Fig. 12. Facies 11, rhythmites, hammer for scale. Note rhythmic $10-20 \mathrm{~mm}$ intercalations of recessive peloidal grainstones and high relief siliciclastic mud-rich layers. Note also chanelling, with carbonate breccia unit on channel floor.
Formation. Interbedded dolomicrites occur within basal portions in this region, but overall the greyishred Bunyeroo Formation mudstones resemble those in section $\mathrm{A}$. The major difference is the relatively thin (c. $175 \mathrm{~m}$ ) nature of the Bunyeroo Formation in the region typified by section B. The upper boundary to the Bunyeroo Formation is also sharp here, overlain abruptly by a $0.1-0.5 \mathrm{~m}$ greyish-orange dolostone characterized by cuspate features resembling peritidal tepees. This dolostone may correlate with unit 1 of Haines but is more likely to relate to the facies 3 carbonate veneer. Spar-filled fenestral voids, breccias, overthrust carbonate crusts and dolospar-filled cavities are associated with the teepee structures. Teepees are overlain and onlapped by a $0 \cdot 1-0.5 \mathrm{~m}$ pale red microsparry and locally stromatolitic calcarenite limestone. Flaggy beds (units 3 and 4 of Haines) of palered to greenish-grey limestone occur interbedded with siliciclastic mudstones throughout a $100-200 \mathrm{~m} \mathrm{sec}-$ tion overlying the teepee dolostone. Unit 2 (Haines) sandstones and interbedded mudstones are conspicuously absent in this region. The rather ill-defined and 
gradational stratigraphic level which can be traced to nearby canyon incision is indicated by 'C.C' in Fig. 13. All units lying below this level, including the Bunyeroo Formation, ABC Range Quartzite and Brachina Formation (Fig. 2) can be traced to localities where they become truncated by canyon erosion.
Units lying above 'C.C.' can be lithostratigraphically correlated with strata which locally overlie canyonfilling sediments.

The relatively thick Bunyeroo Formation represented by section A (Fig. 13) is interpreted to have been deposited under uniform low-energy conditions,

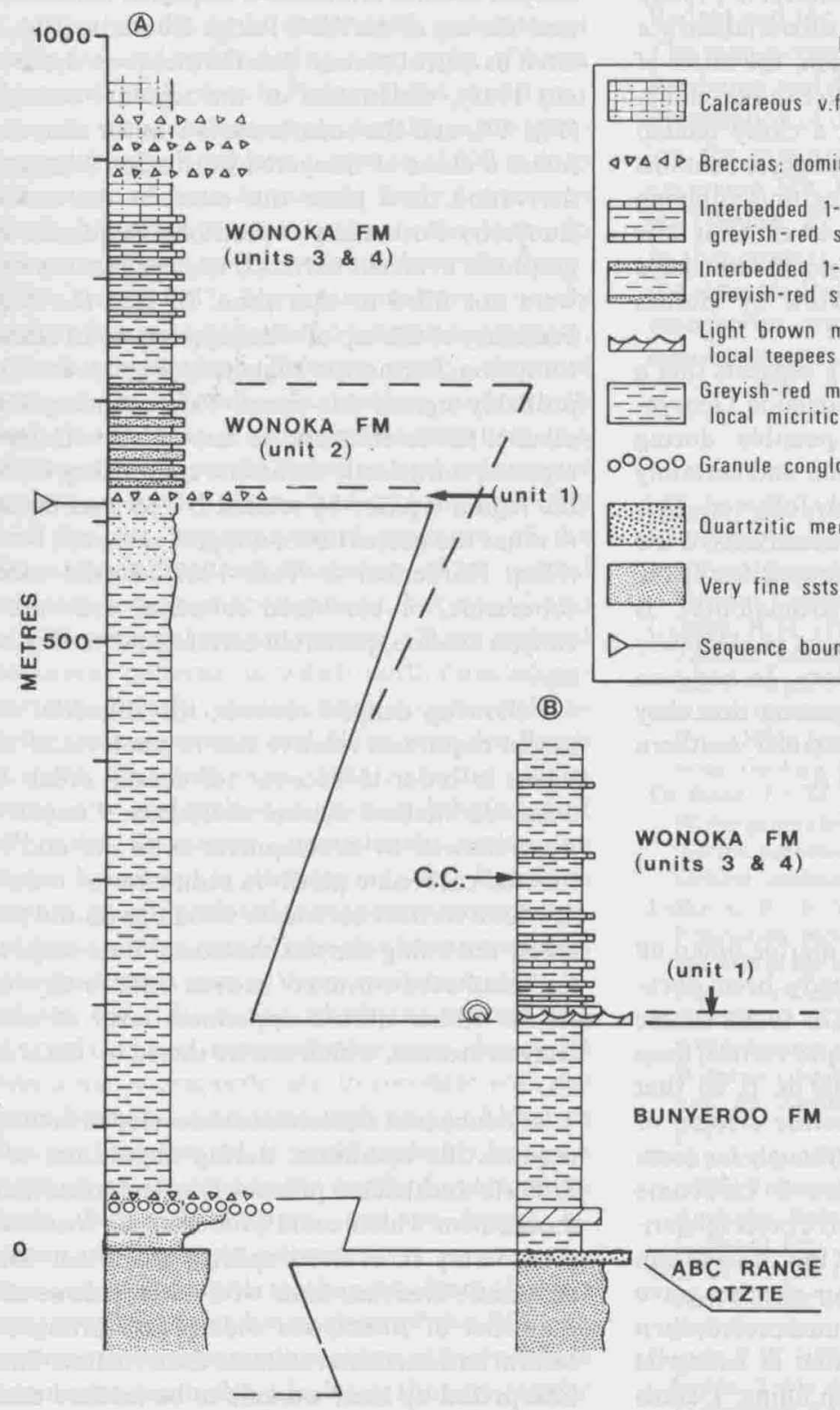

Fig. 13. Measured sections A and B, Fig. 1. Section A typifies the region immediately south of dashed line in Fig. 1; section B typifies the area associated with major canyon incisions north of the line. The unit designation is after Haines, 1986a. Note tepee structures of unit 1 in B. Sequence boundaries are shown by arrows at the left. 
possibly in an outer shelf setting. The formation has the aspect of a depositional sequence which was interrupted prior to the upwards-shoaling which would normally be expected. Wonoka Formation Unit 1, the decimetre-thick dolostone breccia, is interpreted as reworked concretionary dolomite beds, developed on a hiatal surface originally identified as a possible deep water sequence boundary (von der Borch et al., 1988). Unit 1 could alternatively represent a subaerial surface developed on the Bunyeroo Formation, the latter of which was rapidly exposed by a relative sea-level fall. Gostin \& Jenkins (1983) state that a closly related dolostone, the Wearing Dolomite Member, contains beach conglomerates and stromatolites, thus implying a shallow water association at this level. Unit 2 is interpreted as a shallow, locally storm-influenced turbidite fan, following detailed work by Haines (1988).

The character of section B (Fig. 1), suggests that a significant region of the northern Adelaide Geosyncline was exposed and eroded, possibly during deposition of the Bunyeroo Formation and certainly during the interval which immediately followed. This region incorporates virtually all of the canyons of the northern Adelaide Geosyncline. More specifically the tepee dolostone, with associated stromatolites, is clearly indicative of peritidal conditions immediately above the relevant sequence boundary. In addition Unit 2 sandstones are absent, suggesting that they were developed only in the more 'proximal' southern and western areas typified by section $A$.

\section{DISCUSSION}

The case for submarine erosion and marine onlap fill for Patsy Springs Canyon has already been documented (von der Borch et al., 1982, 1988). These authors point out that a sufficiently rapid vertical drop in coastal onlap, of the order of $200 \mathrm{~m}$, is all that would be required to trigger submarine erosion of such canyons. The present work, although far from complete, provides evidence (facies 3 carbonate veneer) that canyon shoulders may have been subaerially exposed prior to canyon filling. If this observation is valid and the 'above storm and fair weather wave base' structures have been correctly interpreted, then an alternative model is necessary, that of subaerial erosion and subsequent coastal-onlap filling. Details and the rather drastic implications of such a model are discussed below.

Subaerial erosion of a kilometre-deep canyon, following deposition of an inferred marine sequence (Bunyeroo Formation, Figs 2 \& 13), requires relative lowering of base level by a minimum of $1 \mathrm{~km}$. A eustatic sea-level fall of this order is clearly out of the question (Watts \& Thorne, 1984). Thus tectonic uplift, or some process which could lower water-level by a minimum of $1 \mathrm{~km}$, would be necessary. Although canyon erosion related to a sequence boundary at or near the top of the ABC Range Quartzite (Fig. 2) was cited as one of several possibilities (von der Borch et al., 1988), constraints of the regional stratigraphy (Fig. 13), and the occurrence low in the canyon fill of facies 6 clasts of Bunyeroo Formation (canyon wail) derivation, now place this event at the end of the Bunyeroo Formation depositional sequence: Stratigraphical evidence certainly implies that the canyons were not filled at that time. In fact the sequence boundary at the top of what appears as an attenuated Bunyeroo Formation sequence (Figs 2 \& 13) most probably signals this event. This boundary marks a distinct facies shift and is associated with the thin, regional intraclastic dolostone comprising Unit 1 . In the region typified by section B and possibly section A it has the properties of a type 1 sequence boundary (Haq, Hardenbol \& Vail, 1987). Initial subaerial, submarine, or combined subaerial and submarine canyon erosion, probably correlates with this boundary.

Following canyon erosion, the subaerial erosion model requires a relative rise in sea-level of at least $1 \mathrm{~km}$, in order to account for coastal onlap by the observed shallow marine sediments. Canyon filling was followed by development of in situ and resedimented carbonate platform sediments of units 3 and 4 , which formed carbonate build ups on the progressively drowning canyon shoulders. Late stage lateral and headward erosion of canyon walls finally resulted in the rather diffuse uppermost level of observed canyon erosion, which can be traced to 'C.C.' in Fig: 13.

The subaerial erosion model developed in this paper requires the operation, during deposition, of some hitherto unexpected process. One tectonically-related mechanism which could produce such localized and presumably short lived uplift is diapirism. Diapiric carbonate breccias, some with outcrop dimensions of the order of $30 \mathrm{~km}$, are widespread throughout the central and northern Adelaide Geosyncline. These are interpreted by most workers to be leached remnants of salt structures, and their intrusion and associated salt removal profoundly affected late Proterozoic sedimentation (Lemon, 1986). There is clear evidence 
of diapiric movement during Wonoka Formation deposition (Haines, 1986b), and Abbott (1986) produced evidence for a pulse of diapiric activity during deposition of the lower Bunyeroo Formation. Uplift of the order of $1 \mathrm{~km}$ has been attributed elsewhere to salt diapirism, for example in Iran (Jackson \& Talbot, 1986), admittedly in a compressional rather than extensional setting. An alternative tectonic mechanism relates to the little understood processes of thermally-induced uplift during some types of basin development. The Colorado Plateau (USA) uplift may be a specific large scale example. Smaller scale intrabasinal uplift, which resulted in erosion of $600 \mathrm{~m}$ deep palaeocanyons of Late Jurassic to Early Cretaceous age, probably produced the Tookoonooka Dome in the Eromanga Basin in Queensland, Australia (Newton, 1986; Young, 1987). These canyons have variously been interpreted as subaerial and submarine in origin.

A mechanism which explains many observed features of the Wonoka Formation, and which currently is the focus of considerable attention, is a Messinian-style evaporitic lowering and subsequent raising of base level. This mechanism would not only account for the apparent rapid exposure of the Bunyeroo Formation and truncation of its normal depositional sequence development, but would also explain (1) subaerial canyon erosion; (2) the regional palaeocurrent patterns, in which north-directed palaeocurrents clearly existed prior to, as well as following, canyon erosion and filling (von der Borch et al., 1985; Eickhoff et al., 1988); (3) the sudden appearance of widespread calcareous lithofacies of the Wonoka Formation, immediately above the sequence boundary at the top of the Bunyeroo Formation, possibly related to evaporative concentration of basin waters; and (4) the short stratigraphical interval in regions remote from canyon erosion ( $c$. $300 \mathrm{~m}$, see Fig. 13), during which the erosion and filling event occurred. In a predictive sense, this model requires a major evaporite unit to correlate with the sequence boundary associated with unit 1 . Although this has not been located, it would probably lie down the regional palaeoslope to the north of outcropping Adelaide Geosyncline strata, and be buried by Cambrian and Mesozoic sediments.

These and other possible mechanisms for explaining the stratigraphy and sedimentology of the Wonoka Formation canyons remain the subject of lively debate and ongoing research. What is clear is that spectacular syndepositional events influenced erosional and depositional processes during emplacement of the Wonoka Formation. Correct interpretation of these events will have a significant bearing on the perceived history of the Wilpena Group in the Adelaide Geosyncline.

\section{ACKNOWLEDGMENTS}

Research support for this study was provided by Esso Australia Ltd, the Flinders University Research Budget and the Australian Research Grants Scheme. The manuscript was typed by Inara Stuart and Nena Bierbaum and draughting was done by Gail Jackson. Preparation of the manuscript was triggered by active 'on the outcrop' discussion with members of IAS excursion 27b, 1986. Observations by P. Homewood, R. Tillman, R. Walker and B. Zaitlin were relevant in this context. R. Walker, in particular, converted the senior author to the 'shallow water fill' model. The manuscript was considerably improved following comments by J. Grotzinger and R. Walker.

\section{REFERENCES}

Aввотт, S.T. (1986) Stratigraphy and sedimentation of the Wilpena Group near Beltana Homestead, central Flinders Ranges, South Australia. Unpublished Honours BSc Thesis, Flinders University, South Australia.

CARTER, R.M. (1979) Trench-slope channels from the New Zealand Jurassic: the Otekura Formation, Sandy Bay, South Otago. Sedimentology, 26, 475-496.

CHRISTIE-BLICK, N., GROTZINGER, J.P. \& VON DER BORCH, C.C. (1988) Sequence stratigraphy in Proterozoic successions. Geology, 16, 100-104.

DE RAAF, J.F.M., BOERSMA, J.R. \& VAN GELDER, A. (1977) Wave-generated structures and sequences from a shallow marine succession, Lower Carboniferous, County Cork, Ireland. Sedimentology, 24, 451-483.

DIBONA, P. \& VON DER BORCH, C.C. (1986) Wonoka Formation sedimentation, relative sea level, and basin analysis in the northern Flinders Ranges, South Australia. Eighth Aust. geol. Conv., Abstr., 15, 288.

EICKHOFF, K.H., vON DER BORCH, C.C. \& GRADY, A.E. (1986) Incised meandering canyon in the late Proterozoic Wilpena Group; problems of timing and thalweg migration. Int. Sedimentological Congress, Canberra, Abstracts, p. 92.

EICKHOFF, K.H., VON DER BORCH, C.C. \& GRADY, A.E. (1988) Proterozoic canyons of the Flinders Ranges, South Australia: Submarine canyons or drowned river valleys? Sediment. Geol., 58, 217-235.

Gostin, V.A. \& JENKINS, R.F. (1983) Sedimentation of the early Ediacaran, Flinders Ranges, South Australia. Abstr. geol. Soc. Aust., 9, 196-197.

HAINES, P. W. (1986a) The upper Wilpena Group at Bunyeroo Gorge, a one day excursion. In: Peterozoic to Cambrian Sedimentary Environments and Resource Potential, Flinders Ranges, South Australia. (Compiled by C. R. Dalgarno). Guidebook, Eighth Aust. geol. Conv., 1986, Geological Society of Australia. 
Haines, P.W. (1986b) Late Proterozoic carbonate shelf to shale basin transition, Wonoka Formation, Flinders Ranges, South Australia. Abstr. geol. Soc. Aust., 15, 92.

HaINes, P.W. (1988) A late Proterozoic storm-dominated carbonate shelf sequence: the Wonoka Formation in the central and southern Flinders Ranges, South Australia. Brian Daily Memorial Volume. Spec. Publ.geol. Soc. Aust., (in press).

HaQ, B.V., HaRdenbol, J.R. \& VaIL, P.R. (1987) Chronology of fluctuating sea levels since the Triassic. Science, 235, 1156-1167.

JACKson, M.P.A. \& TALBOT, C.J. (1986) External shapes, strain rates and dynamics of salt structures. Bull. geol. Soc. Am., 97, 305-323.

LEMON, N.M. (1986) Adelaidean sedimentation adjacent to the Enorama Diapir, central Flinders Ranges, South Australia. Abstr. geol. Soc. Aust. 15, 119-120.

Newton, C.B. (1986) The Tintaburra Oilfield. J. Aust. petrol. Explor. Ass., 28, 334-352.

PRAVE, A.R. (1985) Can hummocky cross-stratification be formed below effective wave base? Geol. Soc. Am., Abstr. with Progs., 117, 693.

Preiss, W.V. (ed.) (1987) The Adelaide Geosyncline: late Proterozoic stratigraphy, sedimentation, palaeontology and tectonics. South Australian Dept. of Mines \& Energy Bull., 53.

Rutland, R.W.R., Parker, A.J., Pitt, G.M., Preiss, W.V. \& MurRell, B. (1981) The Precambrian of South Australia. In: Precambrian of the Southern Hemisphere. (Ed. by D. R. Hunter). Developments in Precambrian Geology, 2, 309-360, Elsevier, Amsterdam.
Shepard, F.P., Marshall, N.F. \& Mcloughlin, P.A. (1974) Currents in submarine canyons. Deep Sea Res., 21, 691-706.

VISSER, M.J. (1980) Neap-spring cycles reflected in Holocene subtidal large-scale bedform deposits: a preliminary note. Geology, 8, 543-546.

VON DER BORCH, C.C. (1980) Evolution of late Proterozoic to early Palaeozoic Adelaide Foldbelt, Australia : comparisons with post-Permian rifts and passive margins. Tectonophys., 70, 115-134.

VON DER BORCH, C.C., Christie-Blick, N. \& Grady, A.E. (1988) Depositional sequence analysis applied to upper Proterozoic Wilpena Group, Adelaide Geosyncline, South Australia. Aust. J. Earth Sci., 35, 59-71.

von DER BORCH, C.C., Grady, A.E., Aldam, R., Miller, D., Neumann, R., Rovira, A. \& Eickhoff, K. (1985) A large-scale meandering submarine canyon: outcrop example from the late Proterozoic Adelaide Geosyncline, South Australia. Sedimentology, 32, 507-518.

VON DER BORCH, C.C., SMIT, R. \& GRADY, A.E. (1982) Late Proterozoic submarine canyons of Adelaide Geosyncline, South Australia. Bull. Am. Ass. petrol. Geol., 66, 332-347.

WATTS, A.B. \& ThORnE, J. (1984) Tectonics, global changes in sea level and their relationship to stratigraphical sequences at the US Atlantic continental margin. Mar. Petrol. Geol., 1, 319-339.

Young, I. (1987) Late Jurassic-early Cretaceous channels and associated fill, Eromanga Basin (ATP 259P), Queensland. Aust. Soc. explr. Geophys. Mtg. Proc., Perth. 
Copyright $@ 2003$ EBSCO Publishing 